\title{
An insurance fund as a tool for preserving and accruing the innovative and environmental potentials of economic systems
}

\author{
Veronika Frolova ${ }^{1, *}$, Lubov Shamina ${ }^{2}$ \\ ${ }^{1}$ St. Petersburg State Marine Technical University, St. Petersburg, 190121, Russia \\ ${ }^{2}$ Baltic State technical university "VOENMEH", St. Petersburg, Russia
}

\begin{abstract}
Considering the 2030 Russian Federation environmental policy and the Environmental Safety Strategy for the period until 2025, which make us re-evaluate the role of insurance as a whole, expanding it to include environmental insurance and environmental innovations, we determine four main types of environmental investments in sustainable innovations. Additionally, we look into the possibility of further development of environmental insurance in view of sustainable economics.
\end{abstract}

\section{Introduction}

The basics of 2030 state environmental policy of the Russian Federation, approved by the RF President on April 30, 2012, proclaim that the aim of the state environmental policy is to ensure sustainable economy, to preserve favorable environment, biological diversity and natural resources for meeting the needs of the current and future generations, to realize the right of every individual for favorable environment, to consolidate law and order in terms of environment protection and to provide environmental safety. The Environmental Safety Strategy for the period until 2025, adopted by the Decree of the RF President on April 19, 2017 No. 167 (hereinafter the Strategy), proclaims environmental safety as an integral part of the national security of our country. Clause 26 of the Strategy prescribes, among other things, that fundamental and applied scientific research should be activated in the field of environment protection and natural resource management, including green technologies, introduction of innovative and environmentally friendly technologies, and development of ecologically safe production processes. In our opinion, in the era of noonomy, which is accompanied by profound changes in economic and social life [1,2], new approaches should be used to form sources and implement mechanisms for resource provision of such measures. In this respect, it seems especially important to reconsider the role of insurance as a whole, environmental insurance and environmental innovations in economic systems.

\section{Literature review}

Today insurance is developing dynamically and calls for analyzing the global and national experience in the development of insurance science $[3,4]$.
The problems concerning simulating a complex of eco-systems are looked at by contemporary scientists [5].

In the last decade, microinsurance has emerged as a popular instrument in development policy to manage disaster risks and increase resilience in the developing world. An economic system can be adapted to the changes in the environment [6] through realizing environmental innovations in economic systems. It is widely recognized that innovation is a key factor for corporate competitiveness $[7,8]$ and economic development [9]. Moreover, the innovation process is considered an essential corporate process [10] that has to be managed properly to get profit from it.

Despite a variety of reviewed publications, it has been found out that no research studies have been done in the field of applying an insurance fund as a tool for preserving and accruing the innovative and environmental potentials of economic systems.

\section{Hypothesis}

It is quite obvious that production is a material basis for human existence in a certain social form. The task of the present day is to preserve and accrue the innovative and environmental potential of economic systems. In the authors' opinion, insurance is one of the efficient tools for attracting investments to preserve and accrue the innovative and environmental potential.

The objective of this study is to investigate whether there is a relationship between the accruing potential of environmental innovations of economic systems and insurance.

Let us look at the compulsory element of social reproduction - an insurance fund. An insurance fund is created as a reserve of material and monetary resources to cover ultimate damage caused by natural disasters, anthropogenic factors and various accidents.

\footnotetext{
* Corresponding author: veronika f@list.ru
} 
The resources of the insurance fund can be used to activate fundamental and applied scientific research in the field of environment protection and natural resource management, including green technologies, introduction of innovative and environmentally friendly technologies, and development of ecologically safe production processes. Thus, the insurance fund can largely solve the objectively existing contradiction between man and nature. At the same time is ensured the continuity of the process of social reproduction and environmental innovation implementation.

It is the insurance fund that can be an investment tool for preserving and accruing the innovative and environmental potentials of economic systems. Thus, all types of insurance always have an environmental component.

\section{Methodology}

The final document of the United Nations Conference Rio+20 [3] highlights the commitment of the country leaders and governments to sustainable development and building an economically, socially and environmentally stable future for our planet for the present and future generations. The environmental component cannot be ensured without environmental innovations. Currently, the significance of insurance must grow considerably, as it is truly intended to become an important method of risk management, a system of national protection of economy, a powerful internal investment and innovation source, regulator and stabilizer of the financial system.

Insurance is directly related to such complicated categories as damage and risk.

Within the concept of noospheric sustainable development, in their work the academicians of the Russian Academy of Sciences [11] put on the agenda such an issue as creating and developing a new interdisciplinary approach, which can be conditionally called the synergy theory of risk. The concept of the authors implies that the experience of Russia and the world and previous developments can be used to build a new science - mathematical theory of safety and risk, which, in particular, can serve as a basis for the insurance industry. Non-linear dynamics and computer modeling can be used as a methodological groundwork for such a theory. Now it is time to create a new paradigm in the field of risk management. Catastrophic behavior is common for a majority of complex systems. It is common for them to have general regularities and they can be identified through non-linear dynamics and system analysis. A hierarchy of mathematical models must be built and effective management strategies should be suggested.

The objective conditions of production act as an underlying basis for maintaining the insurance fund. These conditions do not depend on the will and consciousness of people. The functional aspect of the insurance fund, firstly, reveals its nature, and, secondly, strictly constrains the scope of its application by the limits of material and production activities. The insurance fund contributes to the economic progress of society. Substantial material and financial resources, accumulated in the insurance fund, together with its targeted use for indemnity serve as a source of investments in the economy $[12,13]$.

In the national and foreign literature quite a range of terms are used to refer to investments in the field of environmental protection, such as "environmental investments", "eco-investments", "environmentally friendly investments", "environment-enhancing investments" $[14,15]$.

The insurance fund provides for repaying the sequences of risks accepted for insurance coverage. However, the insurance fund includes not only the reserves for making insurance compensations, but also the reserves for financing preventive measures. I.e. the price of insurance services allows for expenses related to performing a preventive insurance function, which can serve as a source to finance fundamental and applied research studies in the field of environment protection and natural resource management, including green technologies, introduction of innovative and environmentally-friendly technologies, development of sustainable production processes.

\section{Results}

Given the four main directions of environmental activity, four main types of environmental investments in sustainable innovations can be pointed out:

1. Resource saving - investments aimed at protecting non-renewable resources.

2. Resource reproducing — investments aimed at protecting and reproducing renewable resources forest, soil, fish, and other biological resources widely used in the economy.

3. Environmental protection - investments aimed at protecting the environment (human natural habitat).

4. Environment-conserving — investments aimed at protecting the gene pool (biological diversity) and biogeocenoses (eco-systems) [15].

But it should be noted that these amounts are negligibly small in comparison to the entire volume of insurance reserves. By allocating money of insurance funds in the economy through a system of financial intermediaries, insurance organizations lose control over the use of financial resources in terms of environmental safety.

So an insurance fund can be considered an efficient tool for preserving and accruing the scientific, innovative and environmental potentials of economic systems provided that the control function of insurance is expanded.

\section{Discussion and conclusions}

The inexpediency of further development of society in terms of forming additional environmental insurance funds can be proven. A possible way is to improve management of all types of insurance with simultaneous substantial expansion of operations aimed at making insurance greener as a whole and all its types in 
particular, as well as to develop investment control through a system of environmental auditing of all investment innovative projects, funded by the insurance sector through financial institutions.

\section{References}

[1] J.B. Barney, Strategic factor markets: expectations, luck, and business strategy, Manage. Sci., 32, 10, 1231-1241 (1986).

[2] S.D. Bodrunov, Noonomy, Future: the fourth technological revolution preconditions the need for profound changes in economic and social life Economic recovery of Russia, 2, 6-13 (2018).

[3] The future we want, Final act of the United Nations Conference, Rio de Janeiro (2012) [Electronic resource]. Available at: http://www.uncsd2012.org/.

[4] N.D. Jensen, C.B. Barrett, A.G. Mude, Index insurance quality and basis risk: evidence from northern Kenya, Am. J. Agric. Econ., 98, 14501469 (2016).

[5] R. Seppelt, F. Müller, B. Schröder, M. Volk, Challenges of simulating complex environmental systems at the landscape scale: a controversial dialogue between two cups of espresso, Ecol. Model, 220, 3481-3489 (2009).

[6] A. Shmatko, V. Yanovskiy, L. Shamina, Adaptability as a tool for managing an enterprise in a turbulent external environment, Advanced Science Letters, 24, 9, 6323-6325 (2018).

[7] M.E. Porter, Competitive strategy: techniques for analyzing industries and competitors, New York: Free Press, 396 (1980).

[8] R. Roberts, Managing innovation: the pursuit of competitive advantage and the design of innovation intense environments, Res. Policy, 27, 2, 159-175 (1998).

[9] J.A. Schumpeter, The theory of economic development, Cambridge: Harvard University Press, 255 (1934).

[10] J.C.O. Matias, D.A. Coelho, Integrated total quality management: beyond zero defects theory and towards innovation, Total Qual. Manage. Bus. Excel, 22, 8, 891-910 (2011).

[11] A.G. Granberg, V.I. Danilov-Danilyan, M.M. Tsikanov, E.S. Shopkhoev, The strategy and problems of sustainable development of Russia in the 21st century, Moscow: ZAO "Izdatelstvo "Ekonomika", 414 (2002).

[12] S.L. Newbert, Empirical research on the resourcebased view of the firm: an assessment and suggestions for future research, Strateg. Manage. J., 28, 2, 121-146 (2007).

[13] V.V. Shakhov, A.S. Millerman, V.G. Medvedev, Theory and risk management in insurance, Moscow: Finances and statistics, 224 (2002).

[14] Risk management: Risk. Sustainable development, Synergetics, Series "Cybernetics: unlimited capabilities and possible limitations", Moscow: Science, 431 (2000).
[15] Yu. Zayats, Searching for an insurance field, Life safety, 10 (2002). 